Scientific Journal Warsaw University of Life Sciences - SGGW

Problems of World Agriculture volume 18 (XXXIII), number 1, 2018: 143-148

DOI: $10.22630 /$ PRS.2018.18.1.13

Harshavardhan Reddy Kummitha $^{1}$, Raqif Huseynov ${ }^{2}$, Michał Wojtaszek ${ }^{3}$

${ }^{1}$ Kaposvár University, Hungary

${ }^{2}$ Szent Istvan University, Godollo, Hungary

${ }^{3}$ Warsaw University of Life Sciences - SGGW, Poland

\title{
Development of Agritourism in the Light of Economics: Case Studies of Italy and Poland
}

\begin{abstract}
Recreational activities pertaining to farmlands are receiving increased attention from both research and practice. One of the major reasons for this heightened importance attributed to farmland tourism is due partly to its potential to advance the local economy and to the benefits it brings for farmers and visitors. Thus, analyzing the role of agritourism in advancing socio-economic prosperity is of pivotal importance. With this background, the paper discusses the economic benefits of agritourism. The results reported in the paper are related to organizations located in Poland and Italy. Agritourism can bring several economic benefits in the countries and regions. What is interesting, the average income from agritourism is about one-third of the overall household income of farmers. Moreover, food service is a crucial factor in the success of agritourism as it brings extra money to farmers. It shows the importance of the relationship between the income obtained from agritourism activities and the benefits local communities gain by engaging in multiple tourism promotion activities.
\end{abstract}

Key words: agritourism; local communities; economic benefits; Poland; Italy

JEL Classification: O13, Q14

\section{Introduction}

One of the fastest developing economic sectors of the European Union in rural areas is tourism. The countryside has become a common tourist destination in most EU countries (Hall et al, 2003; Ainley and Smale, 2010). Tourists can choose from a group of many possible activities such as the combination of tourism and agricultural production (Fennell and Weaver, 1997; Brandth and Haugen, 2011).

There is observed a growing interest in visiting rural areas and the form of such tourism is named agritourism. It is a way of spending free time on an active and working farm. It gives tourists a great opportunity to gain new knowledge. Farms with livestock are a unique attraction and such a holiday can be a wonderful experience. There exist many different types of farming depending on the destination (Fleischer and Tchetchik, 2005). Not only observation but also being involved in some farming tasks make the offer more attractive for agritourists. The significant importance of farmland tourism is due to its potential to advance the local economy and to the benefits it brings for both farmers and

\footnotetext{
${ }^{1}$ MA, PhD student, Kaposvár University, Kaposvár, 7400, Hungary e-mail: harshavardhankummitha@gmail.com ${ }^{2}$ MA, PhD student, Szent Istvan University, Godollo, 2100, Hungary e-mail: raqif $\mathrm{h} @$ yahoo.de

${ }^{3} \mathrm{MA}, \mathrm{PhD}$ student, Department of Agricultural Economics and International Economic Relations WULS-SGGW, Nowoursynowska 166 St., 02-787 Warszawa, e-mail: michal_wojtaszek@sggw.pl; https://orcid.org/0000-0002-5173-8457
} 
visitors. With such a background, the paper discusses the economic benefits of such an activity.

The data used in the paper were collected in selected regions of Poland and Italy. They prove that agritourism brings economic benefits to the selected regions of some countries. The analysis of farmers' household income demonstrates that even $30 \%$ of this income is from agritourism. In addition, food service is a crucial factor of income since it brings extra earnings.

The idea of this paper is to stress the connections between the income from agritourism activities andthe benefits for the local society. The trend of farm tourism started in the past when travellers needed a shelter and meals and the demand for nature motivated the construction of hotels, many of which are still operated by farmers and local landlords.

\section{Literature review: the impact of agritourism on local farms}

From the theoretical point of view, the progress connected with agritourism is an interesting subject of study for the tourism industry. It is good to analyze agritourism farms from the economic perspective. They could be divided into two sources of gaining money: the income from agritourism and the sphere connected with preparing meals for guests. Literature review is helpful to better understand the situation. Agritourism has been the most rapidly growing form of tourism in Poland and Italy. For over 20 years, Italy has been very popular from the perspective of its rapidly developing agritourism. To compare the numbers, in Poland there are more than 8,000 registered agritourism farms and around 12,000 in Italy. Some of the data are from the Italian Institute of Tourism, which provides agritourism services.

Table 1. CPT for resident frequency node (number of times dining at agritourism restaurants) in the study area Tuscany, Italy

\begin{tabular}{l|ccrr}
\hline & \multicolumn{4}{|c}{ Resident frequency } \\
\hline Resident perception of destination & Many times & A few times & Never & Total \\
Advantage & 6 & 115 & 77 & 198 \\
Disadvantage & 4 & 24 & 20 & 48 \\
Other & 1 & 18 & 20 & 39 \\
Total & 11 & 157 & 117 & 285 \\
\hline
\end{tabular}

Source: Italian Institute of Tourism

Table 2. The growth of agritourism in Italy

\begin{tabular}{c|ccc}
\hline Year & $\begin{array}{c}\text { Number of } \\
\text { agritourism farms }\end{array}$ & Number of beds & $\begin{array}{c}\text { Number of farms with restaurant } \\
\text { service }\end{array}$ \\
\hline 1998 & 8,034 & 93,824 & 4,724 \\
2007 & 19,575 & 240,685 & 9,833 \\
Ratio, 20011/1998 & 1.44 & 1.50 & 1.45 \\
\hline
\end{tabular}

Source: Dati Annuali Sull'agriturismo by the Italian National Institute of Statistics (ISTAT). 


\section{Combining agritourism activities with cultural resources}

Table 3 presents an offer of attractions which are prepared for potential tourists and divided into groups depending on whether the services are provided. Some of them exist not only on the farm but also outside of the farmyard.

Table 3. Classification of goods, services and resources used by agritourism.

\begin{tabular}{|c|c|c|c|c|}
\hline $\begin{array}{c}\text { Connection with } \\
\text { local cultural } \\
\text { heritage }\end{array}$ & $\begin{array}{l}\text { Necessity of facility } \\
\text { installation: } \\
M C \text { upward shift }\end{array}$ & $\begin{array}{l}\text { On-farm or off-farm } \\
\text { resources for } \\
\text { utilization }\end{array}$ & $\begin{array}{c}\text { Example of goods, } \\
\text { services and resources } \\
\text { (examples) }\end{array}$ & $\begin{array}{c}\text { Internalization: } \\
M C \text { downward } \\
\text { shift }\end{array}$ \\
\hline $\begin{array}{c}\text { None: } \\
\text { accompanied by } \\
\text { no externality } \\
\text { (facility based) }\end{array}$ & \multirow[t]{2}{*}{ Yes } & \multirow{3}{*}{ On-farm resources } & $\begin{array}{l}\text { Accommodation } \\
\text { facility } \\
\text { Swimming pool } \\
\text { Availability for } \\
\text { disabled }\end{array}$ & None \\
\hline \multirow{4}{*}{$\begin{array}{l}\text { Yes: } \\
\text { accompanied by } \\
\text { externalities } \\
\text { (local culture } \\
\text { based) }\end{array}$} & & & $\begin{array}{l}\text { Restaurant } \\
\text { Equitation }\end{array}$ & \multirow{4}{*}{ Yes } \\
\hline & \multirow{3}{*}{ None } & & $\begin{array}{l}\text { Educational farm } \\
\text { Organic farming }\end{array}$ & \\
\hline & & $\begin{array}{l}\text { On/off farm } \\
\text { private goods with } \\
\text { local traits }\end{array}$ & $\begin{array}{c}\text { Local brand } \\
\text { products }\end{array}$ & \\
\hline & & $\begin{array}{l}\text { Off-farm local } \\
\text { public goods }\end{array}$ & World Heritage Sites & \\
\hline
\end{tabular}

Source: Institute of Tourism This percentage of answers was higher than in other studies on agritourism (Fleischer and Tchetchik, 2005; Barbieri and Mahoney, 2009; Tew and Barbieri, 2012).

There exist three types of local activities and attractions except for restaurants. One of these attractions could be local cultural resources situated off-farm which operators take advantage of, which generate externalities as local public goods. Such examples could be found at World Heritage Sites. They are very positive for the surrounding community and globally important. An extraordinary example is Italy and Poland, which have many such sites, so their impact on the local economy will extend widely. Agrotourism operators take advantage of these Heritage Sites as simple users of externalities. They do not pay for the benefit of externalities as they are local goods.

Another type of local culture that is based on resources consists of local brand products. They could be prepared by the local peasant or by the industry located in such a designated area. In the case of Italy, a good example could be wine with controlled designation of origin. Local brand products exercise positive external effects to the radius of designated local areas in enhancing the production area's attractiveness to tourists. Local brand production is usually privately conducted and locally designated. What is more, such products generate externalities because they also have the characteristic of local public goods. This gives a great chance to local restaurants which sell them to tourists. These products are private goods with an aspect of local public goods, or they have the 
intermediate characteristic of on-farm and off-farm resources because some operators are producers of these goods, while others are only the users.

Projects are not accompanied by special facilities but based only on local culture. Such activities do not require special agritourism facilities that would be different from those needed for conventional farming since they would only generate extra installation costs.

Projects connected with educational farms provide a unique opportunity for people at every age to learn more about rural life by realizing study tours which give an opportunity to visit an active farm. Such initiatives are mostly provided by individual farmers or their families. In these cases, farmers internalize on-farm resources that have a local cultural identity.

Given the considerations above, the next step will be to explore empirically how these types of services influence the prices of agritourism by examining the question of which service will work more strongly: local cultural resource-based services or facility-based tourism.

\section{Results}

Among all the farms that were open to agritourists, over half of them offered meals to their guests. Others were only concentrated on providing a place to sleep. Most of the data were collected by different tourism institutes.

When we analyze the gender of farm owners who provided meal services, even $85 \%$ were women and the rest were men. In some way, it shows something like the specialization of the farm. Women were more engaged in preparing meals, an option which gives extra money to the farm. When we take a look at Nilsson (2002), there is also evidence that farms were mostly managed by women. As far as education is concerned, more than half of them completed secondary education. These days, most young people go to university. The result will be their higher education and master degrees. It is hard to define the size of agritourism farms and give an average number; in some examples, it was even 10 hectares.

Interestingly, when a farm offers rooms to rent and their number is not higher than five, the income from renting rooms and selling meals is free of tax. More than $90 \%$ of farmers have around 5 rooms, and each of them is mostly prepared for two or three guests. The main issue of the owners is satisfying the expectations and needs of agritourists.

\section{Extra value from agritourism activity}

As mentioned above, farmers are sellers who provide products directly for clients.

Thus, the way of communication is the shortest possible as we have the owner and the client, a situation which is comfortable for both sides. A great benefit is the serving of fresh food including all types of products. It is very important for people with allergies or some diseases to know that only traditional production methods were used. It is a great idea to promote some regions and the number of visitors will be growing. The average income from agritourism accounts for even $30 \%$ of the overall income. The aforementioned confirms that agritourism is a great alternative source of income for farmers and their families. 
The second aspect is the impressive percentage of income earned from meal services which are offered to agritourists. For even $1 / 5$, half of the income was from meals. It shows how wonderful and tasty local meals are and when they are combined with the culture, they contribute to a great promotion of every country and region.

The above-mentioned proves that earnings from providing meals to agritourists can make a significant contribution to the total revenue received from agritourism. Selling agricultural products to agritourists improves farm ers' financial situation and quality of life.

\section{Conclusion}

Agritourism in Italy and Poland is receiving increased recognition as a means of rural economic development. Farms which offer agritourism are becoming the most attractive destinations for hard-working people who like to escape from crowded cities during their leisure time. The natural environment creates the most favourable conditions for relaxation. Agritourists can also visit places connected with the country's heritage, discover some regional rules and travel into the past trying traditional dishes, the recipes for which have been known for centuries. From the economic point of view, providing agritourism activities gives extra income to farmers. Such a business allows them to sell products from their farms directly to agritourists. Thus, the distance between the producer and the client is very short.

These results prove that agritourism can become a strong economic driver of rural development and a good direction for the future. Activities connected with agritourism are the leading elements of diversifying rural areas.

\section{References}

Agriturist (1994). Stato e Prospettive Dell'Agriturimo in Italia (State and Perspectives of the agritourism farm in Italy), Agriturist, Rome.

Barbi, A. (1998). Cultural identity of the Slovenian countryside: territorial integrity and cultural diversity from the perspective of rural communities. Agriculture and Human Values, 15, 253-265.

De Beus, J. (1996). The value of national identity. In: Klamer, A., (ed.) The Value of Culture: On the Relationship Between Economics and Arts, Amsterdam University Press, Amsterdam, 166-186.

Ainley, S., Smale, B. (2010). A profile of Canadian agritourists and the benefits they seek. Journal of Rural and Community Development, 5(1), 58-75.

Barbieri, C., Mahoney, E. (2009). Why is diversification an attractive farm adjustment strategy? Insights from Texas farmers and ranchers. Journal of Rural Studies, 25(1), 58-66.

Brandth, B., Haugen, M.S. (2011). Farm diversification into tourism - implications for social identity? Journal of Rural Studies, 27(1), 35-44.

Fennell, D.A., Weaver, D.B. (1997). Vacation farms and ecotourism in Saskatchewan, Canada. Journal of Rural Studies, 13(4), 467-475.

Fleischer, A., Tchetchik, A. (2005). Does rural tourism benefit from agriculture? Tourism Management, 26(4), 493-501.

Hall, D., Mitchell, M., Roberts, L. (2003). Tourism and the countryside: dynamic relationships. In: Hall, D. Roberts, L., Mitchell, M. (eds.) New Directions in Rural Tourism, Aldershot, Ashgate, 3-16.

Jęczmyk, A., Tworek, N. (2009). Wpływ produktów regionalnych na atrakcyjność turystyczą obszarów wiejskich (The influence of regional products on tourist attractiveness of country areas). RN SERiA, 11(4), 129132.

Majewski, J. (2000). Agroturystyka to też biznes (Agritourism is also a business), Fundacja Wspomagania Wsi, Warszawa. 
McGehee, N.G. (2007). An agritourism systems model: a weberian perspective. Journal of Sustainable Tourism, $15(2), 111-124$

Nilsson, P.Å. (2002). Staying on farms: an ideological background. Annals of Tourism Research, 29, 7-24.

Phillip, S., Hunter, C., Blackstock, K. (2010). A typology for defining agritourism. Tourism Management, 31(6), 754-775

Sikora, J. (1999). Organizacja ruchu turystycznego na wsi (Organization of tourism in the countryside), Wydawnictwo WSiP, Warszawa.

Tew, C., Barbieri, C. (2012). The perceived benefits of agritourism: the provider's perspective. Tourism Management, 33(1), 215-224.

Uglis, J., Jęczmyk, A. (2009). Agroturystyka szansą ożywienia obszarów wiejskich (Agritourism as a chance for rural areas boom). Roczniki Naukowe SERiA, 11(4), 341-346.

Bonet, L. (2003). Cultural tourism. In: Towse, R., (ed.) A Handbook of Cultural Economics, Edward Elgar, Cheltenham, 187-193.

Cohen, E. (1988). Authenticity and commoditization in tourism. Annals of Tourism Research, 15, 371-386.

Cracolici, M.F., Cuffaro, M., Nijkamp, P. (2009). Tourism sustainability and economic efficiency: a statistical analysis of Italian provinces. In: Girard, L.F., Nijkamp, P., (eds.) Cultural Tourism and Sustainable Local Development, Ashgate, Surrey, 167-180.

De Beus, J. (1996). The value of national identity. In: Klamer, A. (ed.), The Value of Culture: On the Relationship Between Economics and Arts, Amsterdam University Press, Amsterdam, 166-186.

Di Giovine, M.A. (2009). The Heritage-scape: UNESCO World Heritage and Tourism, Lexington Books, Lanham, MD.

Robinson, M., Evans, N., Long, P., Sharpley, R., Swarbrooke, J. (2000). Tourism and Heritage Relationships: Global, National and Local Perspectives, Business Education Publishers, Sunderland.

Royo-vela, M. (2009). Rural-cultural excursion conceptualization: a local tourism marketing management model based on tourist destination image measurement. Tourism Management, 30, 419-428.

Sharpley, R. (1996). Tourism and Leisure in the Countryside, 2nd ed., ELM Publications, Huntingdon, 73-80.

Sharpley, R. (2005). Managing the countryside for tourism: a governance perspective. In: Pender, L., Sharpley, R., (eds.) The Management of Tourism, SAGE Publications, London, 175-187.

Sharpley, R., Vass, A. (2005). Tourism, farming and diversification: an attitudinal study. Tourism Management, 27, 1040-1052.

Throsby, D. (2001). Economics and Culture, Cambridge University Press, Cambridge.

Throsby, D. (2009). Tourism, heritage and cultural sustainability: three "golden rules". In: Girard, L.F., Nijkamp, P., (eds.) Cultural Tourism and Sustainable Local Development, Ashgate, Surrey, 13-29.

Timothy, D.J. (2007). Managing Heritage and Cultural Tourism Resources: Critical Essays, Volume One, Ashgate, Aldershot.

Timothy, D.J., Boyd, S.W. (2003). Heritage Tourism, Pearson Education, Harlow, 33-34.

Tondini, E. (1995). La Valutazione Dell' Agriturismo (Evaluation of the Agriturismo). Regione Dell'Umbria, Perugia.

Van der Ploeg, J.D., Laurent, C., Blondeau, F., Bonnafous, P. (2009). Farm diversity, classification schemes and multifunctionality. Journal of Environmental Management, 90, Suppl. 2, S124-S131.

Van Huylenbroeck, G., Durand, G. (2003). Multifunctional Agriculture: A New Paradigm for European Agriculture and Rural Development, Ashgate, Aldershot.

Vanslembrouck, I., Van Huylenbroeck, G., Van Meensel, J. (2005). Impact of agriculture on rural tourism: a hedonic pricing approach. Journal of Agricultural Economics, 56, 17-30.

Velázquez, B.E. (2005). Agritourism in Italy. In: Multifunctionality in Agriculture: What Role for Private Initiatives? OECD, Paris, 35-40.

Viganò, L. (2005). La qualità dei prodotti agricoli e agro-alimentari (The quality of agricultural and agri-food products). La Riforma Dello Sviluppo Rurale: Novità e Opportunità, Quaderno n. 1, INEA, Rome, 63-74.

For citation:

Kummitha H.R., Huseynov R., Wojtaszek M. (2018). Development of Agritourism in the Light of Economics: Case Studies of Italy and Poland. Problems of World Agriculture, 18(1), 143-148; DOI: $10.22630 / P R S .2018 .18 .1 .13$ 